\title{
1. Introduction to the women, the study, and the context
}

What is it like to be a college-educated woman in your forties in the US in the middle of the first decade of the twenty-first century? How have mid-life women tried to create lives that have meaning and joy as they have made choices about how to balance employment and family responsibilities? How have they coped with conflicts and hassles that came with their choices? What paths did they travel to create the complex lives they live? What kind of future do they envision going into their fifties and sixties? This book addresses these questions using answers that one group of female graduates from two Northeastern state universities in the US have reported between their final days in college in the early 1980s and the middle of their lives in 2006-07.

The primary focus of both the original study and of this book was to ask women while they were still at college whether or not they expected to be employed during the first three years after the birth of their first child and what they thought it would be like if they were or were not employed mothers. Then one decade and two decades after they first participated in the study we sent written questionnaires to the women asking about the same topics and also asking what they had done and how their families and employers were influencing their choices. Finally, 25 years after we began the study, we tried to find the women again. Those women we did find we interviewed in person or on the telephone and asked them to reflect upon their life course since college and asked them to tell us about their most important life events. As time passed, the study lost track of some women but we have maintained contact with enough women to gain some answers to these questions that might help other women understand their own experiences, share knowledge of similar joys and sorrows, anticipate their own future, and perhaps even learn to avoid some mistakes. To set the stage we can look at how US women's lives changed during the years included in this study.

\section{CHANGING CHILDBEARING AND EMPLOYMENT PATTERNS IN THE US FROM 1980 TO 2006}

There is some consensus that women's home lives in North America changed 
between 1980 and 2006 in ways that were both predicted and unpredicted. Women continued having fewer children and having them later in their lives. For example, in 1980 the average number of children each woman had was three and by 2004 that number had dropped to less than two. The number of all women under 45 who had never had children doubled from 10 percent in 1980 to 20 percent in 2005, and the number of women delaying childbirth also doubled: in 1980 about 7 percent had their first child when they were in their forties compared to 14 percent in 2005 . $^{1}$

The labor force participation of women also changed, with an upward swing between the 1980s and 1990s and a slight decrease after 2000. In the early 1980s, 48 to 49 percent of women with infant children (one year old or under) were in the labor force. By 2001, 55 percent of mothers in the labor force had infant children, down from a record 59 percent in 1998. This marked the first significant decline in the labor force participation of mothers of infants since the US Census Bureau began collecting these data in 1976. In that year, 31 percent of mothers of infants were in the labor force. ${ }^{2}$ In addition to the increase in maternal employment, more women were working full-time and in a broader range of occupations.

During the period of this study several trends have occurred in the range of employment opportunities. The number of women in professional and managerial occupations has gone from 40.6 percent in 1980 through 46.5 percent in 1990 to 51.1 percent in $2006 .{ }^{3}$ Women also have appeared in increasingly higher levels of management in organizations, but not to the extent one would expect from the number of men and women with similar aspirations in middle management. ${ }^{4}$ The glass ceiling that inhibits many women from obtaining promotions seemed to have cracked but was not broken by the change to the twenty-first century.

In the meantime organizations downsized and the number of levels from top to bottom decreased so that promotions were more difficult for everyone to attain. In the beginning of the twenty-first century, downsizing and global competition have so altered the old psychological contract of 'a good day's work and company loyalty in exchange for future job security and promotions' that many people believe that even if they do good work they could still lose their jobs. ${ }^{5}$ Those who do not lose their jobs are increasingly asked to perform the work of laid-off colleagues, thus increasing workloads and decreasing the amount of individual flexibility in how people do their jobs and when they do them. Further changes in technology have seen most managers connected to their workplace day and night through cell phones, beepers, and Blackberries, decreasing the possibility of separation between work and family spheres. ${ }^{6}$ The economic recession of 2008-10 had not occurred when these data were collected, so the many changes that are related to that phenomenon are not reported in this volume. 
In summary, the important work and family changes that occurred during the phases of this study are as follows: more women are having fewer children at a later age; they are employed in management and professional jobs with constrained upward mobility opportunities and overloaded schedules that spill over into their family time. Taking into account these broad changes in US women's lives that have occurred in the past 25 years, we can more clearly understand the specific lives of the women in this study. First, we describe the cultural context and then the women's lives in the early 1980s as the study participants were leaving college. We then introduce the cultural context and their lives after they left their undergraduate days behind and progressed to become mid-career employees and homemakers.

\section{PHASE I}

\section{The Cultural Context}

The first phase of data collection started in the Spring of 1980 and continued through the academic year 1981-82. By the beginning of the 1980 election season the US was reeling over the prolonged hostage crisis in Iran. In 1980 Ronald Reagan defeated Jimmy Carter's bid for a second term and the hostages returned from Iran on Inauguration Day. ${ }^{7}$

The 1980s had The Cosby Show and Family Ties on TV and popular movies included Indiana Jones, Ghostbusters, The Empire Strikes Back, Rain Man, Airplane!, Amadeus, and Rocky III. In music, Madonna, Michael Jackson, Cyndi Lauper, and Bon Jovi were popular entertainers and the Rubik's Cube was a national craze. ${ }^{8}$ The underdog US hockey team defeated the highly favored Russian team in the semifinals of the 1980 Lake Placid Olympics. The US team would go on to defeat Finland for the gold medal and Bjorn Borg defeated John McEnroe in the final of Wimbledon. ${ }^{9}$ This was the US popular cultural atmosphere as the study began.

\section{The Women who Participated in this Study}

The women who provided the Phase I data-set in 1980 included 202 respondents out of 300 randomly selected juniors and seniors from Rutgers, the State University of New Jersey, who filled out a written questionnaire placed in their campus mail boxes. This sample was expanded to 433 women in 1981 and diversified by sending out a second wave of about 100 questionnaires to seniors in the Temple University School of Business and School of Social Work, and 200 more seniors at Rutgers and Douglass Colleges of Rutgers University. 
The women in the final group of Phase I came primarily from small towns or rural areas in the US Northeast and they were often the first or second generation to attend college in their families. About 17 percent were AfricanAmerican and 40 percent were Catholic. The majority had fathers and mothers with a high school education or less. Less than one-third had mothers who were employed when their daughters were less than three years old, but about three-quarters of their mothers were employed by the time these students were teenagers. In college, about half of the participants were in a steady relationship but only about 18 percent were engaged or married. When they began to participate in the study about half of the women also had held some kind of job for a total of a year or more if one added all their work experience, and they worked primarily in service industries.

\section{Employment and Family Plans of College Women in 1980-81}

In college most of the women had plans that included a general goal or direction or occupation, but the majority had limited career plans with few alternatives or back-up strategies other than a general idea of what kind of job to seek after college. In the early 1980s about 45 percent of these young women believed they would have two children and about one-third believed they would have three children. Their average plan for spacing between children was two to two and a half years for white women and one and a half to two years for African-American women. Their plans for childrearing primarily consisted of plans about what to teach their 'perfect' children. Few women had plans that anticipated illness, disability or absence of their spouse or children.

In contrast to their career plans and childrearing plans, most women had well thought out and specific plans for integrating their employed work and childrearing plans. The strategies for combining employment and childrearing most commonly included working part-time, waiting until after the children were at school to return to work, hiring help in the home, placing their children in day-care centers, and/or getting their husbands to help. ${ }^{10}$

Mothers and potential husbands also influenced women's plans. Some women wanted to do as their mothers had done, while a slightly smaller number of others saw their mothers as poor examples and wished to make different plans. Women wanted or expected to have a particular kind of spouse in order to have the kind of lives they desired, usually someone who would help with housework and childcare. Those who already had husbands or partners had a more realistic picture of limited assistance and their partners had more consequential effects on these women's plans. Women who were actually part of a couple during college were more likely than those not involved with a partner to have developed specific work and childrearing plans beyond 
graduation, and to have more detailed alternative strategies for combining work and childrearing if their first strategies were blocked. ${ }^{11}$

Because plans for combining work and childrearing were the central focus of this study, one specific question addressed their plans to combine these two activities: 'How likely is it that you will work during the first three years after childbirth?' As college women, one-third of white women and two-thirds of African American women said they expected to return to work in one year or less following childbirth. Half of the white women and 84 percent of the African American women believed they would return to work within three years of the birth of their first child. ${ }^{12}$

A previous volume describes how the women in this study changed during the first decade of their post-college lives ${ }^{13}$ and several academic articles describe various aspects of their plans and their decision-making process. ${ }^{14}$ These other sources may be consulted for a more detailed account of the information that is summarized here.

\section{PHASE II}

\section{The Cultural Context}

The second phase of data collection occurred in the 1990-91 academic year. George H.W. Bush had been elected President, and the US was entering a war in the Middle East. Bush led the United Nations coalition in the 1990-91 Gulf War to remove Saddam Hussein's Iraqi forces from Kuwait. An economic recession from July 1990 to March 1991 was a contributing factor to his defeat in the 1992 Presidential election. ${ }^{15}$ Popular culture in the 1990s included the drug Viagra, Beanie Babies toys, Furbies toys, and Boy Bands. Music hits included 'Achy Breaky Heart' by Billy Ray Cyrus, 'Ice Ice Baby' by Vanilla Ice, 'Macarena' by Los Del Rio, 'Vogue' by Madonna, 'Supermodel' by RuPaul, 'Wannabe' by the Spice Girls and 'Candle in the Wind' by Elton John. ${ }^{16}$ Popular movies included Saving Private Ryan, Silence of the Lambs, Legend of the Fall, Philadelphia, Evita, Forrest Gump, and Pulp Fiction. In sports, the decade began with Buster Douglas defeating Mike Tyson to become the heavyweight boxing champion on 11 February 1990, and ended with the US women winning the World Cup soccer tournament, 10 July 1999. ${ }^{17}$ In this US cultural context, we sought out the women and asked them to answer a follow-up mailed questionnaire.

\section{Young Career Women and New Mothers in 1990-91}

The women who responded to Phase II were less likely to be African- 
American, less likely to have lived in a big city and less likely to have intended to return to work following childbirth than those who responded to Phase I but did not respond to Phase II. This was probably due to a lower response rate from one university which had more urban, African-American, career-oriented students.

The 205 women who participated in Phase II of this study had maintained an educated, middle-class lifestyle during the 1980s. Of these women onethird went on to earn graduate degrees and 8 percent completed an MD, LLD or $\mathrm{PhD}$ degree. The most common occupations included manager (25 percent), housewife (11 percent), scientist (9 percent), and computer specialist (8 percent). Over 72 percent were working 35 or more hours per week in jobs they had held for the past three years. Their average income was slightly over $\$ 30000$ and for those who were married (about 90 percent), their spouses made about $\$ 50000$ annually in 1990 . When asked about the factors that might encourage them to change jobs or leave their current employer, the most common responses were to have more time with their children, to care for their children because they could not find adequate childcare, and to find a more challenging job with more opportunity to advance.

Family life was delayed longer than anticipated. In 1980, 91 percent had expected to have had their first child within ten years, but by 1990, only 46 percent of the women had at least one child; of those who had children, 20 percent had two children and 4 percent had three. Over 95 percent of those who had not yet had children in 1991 expected to have a child within the next five years. The participants generally believed that they were the best caretakers for their children, whether or not they were the only caretakers and most were self-confident in their abilities at home and at work.

After collecting the data for Phase II we divided the women into four groups depending upon whether or not they intended to be employed during the first three years following the birth of their first child and what they actually did. The cut-off point was chosen to be three years after childbirth because by the age of three many children are in nursery school and childcare is somewhat easier to obtain for this age and above than for infants and toddlers. This child age was a common age for mothers to return to work in the early $1980 \mathrm{~s}$ when the study began, although mothers actually returned to work much earlier in the 1990s and into the twenty-first century. Women working more than ten hours per week in paid employment were considered employed for purposes of this four-way classification. Thus the employed group includes part-time employees. In cases where women had not yet had a child by 1990, intentions to return to work if they were to have a child were used to classify the women.

The four groups were homemakers, breadwinners, nesters, and careerists. Homemakers reported a higher probability that they would stay home after 
childbirth in both Phase I and Phase II and careerists reported a higher probability that they would return to the labor force in both Phase I and Phase II. Breadwinners thought they would stay home in Phase I but actually reported in Phase II that they had returned to employment within the first three years after childbirth. Nesters changed their minds in the opposite way - reporting that they believed they would return to work in Phase I but that they had actually stayed home after childbirth in Phase II. The details of the comparison of women in each of these groups formed the basis of the first book which reports the results of this study and further details are available in that volume. ${ }^{18}$

\section{PHASE III}

\section{The Cultural Context}

Phase III of these data were collected in the 2000-01 academic year. Since Phase II many political changes had occurred. In 1993 the Clinton Democrats entered the White House, but by 1995 the Republican Party dominated the legislature. Hillary Clinton's strong role in the administration led to criticism of the First Lady. Bill Clinton fulfilled a campaign promise by signing the Family and Medical Leave Act of 1993, which required large employers to allow their employees to take unpaid leave because of a family or medical emergency. Clinton's proposals to rewrite health care failed but revisions of welfare legislation passed, and gays were partially tolerated in the military (under the 'don't ask don't tell' rubric). Clinton presided over continuous economic expansion, reductions in unemployment and growing wealth through a large rise in the stock market. However much of Clinton's presidency was overshadowed by scandals, including the Kenneth Starr-led Whitewater investigation with no finding of wrongdoing by the Clintons and the President's sexual encounters with Monica Lewinsky, for which he was impeached by the US House of Representatives but not convicted by the US Senate in votes largely following party lines. ${ }^{19}$

In 2000, George W. Bush became the winner of one of the closest general elections in American history - defeating Democratic Vice President Al Gore by five electoral votes, while Gore won a plurality of the nationwide popular vote in a contest ultimately decided by the US Supreme Court. The legislature was Republican, 'Family Values' was the buzzword of the day and the stock market crash of 2000-01 was led by the technology sector mired in a millennium hangover. After the 9/11/2001 attack on the World Trade Center Twin Towers, George W. Bush announced that the US would implement a policy of preemptive strike against any nation it saw as a threat, and the war on terrorism in Afghanistan and Iraq began. ${ }^{20}$ 
In 2000, reality shows became prime time models for TV - Who Wants to Marry a Millionaire and Survivor were popular. Other pop culture icons included digital music copied on Napster, DVDs, wireless communications, cell phone mania, scooters, and the fourth Harry Potter book. ${ }^{21}$ At the movies, Crouching Tiger, Hidden Dragon and Gladiator were well attended and in sports, Evander Holyfield regained the world heavyweight title, becoming the first boxer to win the world heavyweight title four times. Lance Armstrong won the Tour de France, Michelle Kwan was the Ladies' Olympic ice skating champion and Venus Williams won the US Open and Wimbledon tennis championships. ${ }^{22}$ In this cultural context we again asked the study participants to answer a mailed questionnaire.

\section{Careerists, Entrepreneurs, and Homemakers in 2000-01}

In 2001, we located addresses for 265 women and sent them questionnaires. Of those, 96 usable responses were received (36 percent of those sent questionnaires and 22 percent of the original participants). Though this would generally be considered a rather low response rate, 36 percent of the women we contacted retained an interest in the study 20 years after its inception, despite lives busy with work and children.

Among the Phase III respondents 29.2 percent had obtained graduate degrees by 2001. The respondents had increased their family size and their family income considerably. In 2001, 83 percent had had at least one child (up from 46 percent in Phase II), 63 percent had two children and 26 percent had three or more children (up from 4 percent in Phase II).

In Phase III, at least 78 percent of respondents were employed (up from 72 percent in Phase II) and 22 percent were homemakers (in detail, 20 were entrepreneurs, 52 were employees, 20 were homemakers and the remaining four did not answer the employment question clearly). The average income of the women was over $\$ 40000$ (an increase of about $\$ 10000$ over Phase II) with a range from less than $\$ 20000$ per year to one woman who made over $\$ 180000$ per year. In Phase III, their spouse's income averaged over $\$ 80000$ per year (an increase of about $\$ 30000$ during the past ten years) with a range from one person who earned less than $\$ 20000$ to ten who earned over $\$ 200000$, the highest option given in the salary range question.

\section{PHASE IV}

\section{The Cultural Context}

By 2005, many in the US were beginning to wonder how the nation could 
extract itself from the wars in Afghanistan and Iraq and the Republican majority in the legislature was hotly contested in 2006. Walk the Line, Wallace and Gromit and Cinderella Man were the top movies of the day, ${ }^{23}$ My Name is Earl and Grey's Anatomy held sway on many HD TVs and Kelly Clarkson from American Idol was singing a pop hit 'Since U Been Gone'. ${ }^{24}$ This is the context of the final interviews, collected in 2006-07.

\section{Participants in Phase I Compared to Participants in Phase IV}

In 2005-06, we began to try to find participants again and with the help of the alumni/ae offices of both universities. We gathered 76 responses to a mailing to all women for whom we had an address, asking women if they would be willing to be interviewed in person or on the telephone. Of these respondents, 71 completed interviews were conducted and coded. This is 93 percent of the women contacted, 73 percent of those we had found in Phase III, 34.6 percent of those we had found in Phase II, but only 16.4 percent of the original college women who participated in Phase I of the study. Because of the small response rate compared to the original group of women, we must be very cautious in generalizing to the whole sample let alone for a population of all women who graduated from Northeastern US universities in the early 1980s.

We did do some statistical analyses to compare those who responded to Phase IV to those who did not respond to Phase IV but who participated in Phases I, II or III using background data available from respondents in each phase. We found that the Phase IV respondents were remarkably similar to the original Phase I sample in all but two background variables and one significant study variable. The women interviewed in Phase IV were not significantly different from those who responded to Phase I in age, birth order, mother's or father's education, religion, or residence in rural area, town or city when growing up. The Phase IV respondents also did not differ from those who responded in Phase I in terms of total children expected, age they expected to have their first child, or length of time they expected to return to employment after childbirth. The respondents to Phase IV also did not differ in education level from what the respondents in Phases I, II, or III achieved, or in average own income or average spouse's income expected in Phase I, or earned in Phases II, or III.

The two significant background differences between those who responded to Phase IV and those who responded to Phase I were in marital status when in college (64.8 percent were not in any relationship in college of those who did not respond to Phase IV, compared to 51.5 percent of those who did respond in Phase IV) ${ }^{25}$ and mothers (but not fathers) born in the US (87.3 percent of respondents in Phase I, compared to 97 percent of Phase IV respondents). ${ }^{26}$ 
The most relevant variable that has a clear implication for drawing conclusions about the women in Phase IV was that they were more likely to predict in Phase I that they would work following childbirth than those women who did not respond to Phase IV but who participated in Phase I. ${ }^{27}$ We did not ask many questions in the interviews that required numerical answers that could be statistically analyzed and compared with Phase I, II, and III responses so we have not weighted cases in these reports of interviews conducted during Phase IV. However, it is important to remember not to use the Phase IV descriptions to draw conclusions comparing the number or percentage of women who did or did not do as they predicted in college or who became or did not become homemakers in their mid-life, since the Phase IV sample under-represents women who thought they were unlikely to be employed during the first three years after the birth of their first child.

\section{Career Women, Part-time Workers, Homemakers, and Entrepreneurs in 2006-07}

The religious heritage of 28 percent of the women who did respond in Phase IV was Protestant, 42 percent were raised as Catholics, and 13 percent were raised in the Jewish faith. The majority of the women (81 percent) were raised in a town, and the rest were about evenly divided between growing up in the country and growing up in a large city. All graduated from a four-year college course, 38 percent went on to get a Master's degree and 8 percent completed a $\mathrm{PhD}, \mathrm{MD}$, or LLD degree. The most common occupation was as a teacher (10 percent), followed by scientist (9 percent), and some type of managerial position ( 9 percent). At the time of the interviews 23 percent were not employed, 50 percent were working 40 or more hours per week and the remaining 27 percent were employed part-time. About one-quarter of the women had personal incomes of under $\$ 20000$ per year and 23 percent were making more than $\$ 100000$ per year whereas less than 5 percent of spouses were making under $\$ 20000$ per year and 61 percent of spouses were making more than $\$ 100000$ per year.

Most women were married, 83 percent married once and another 9 percent married twice. About half of the women (53 percent) who have had a child had their first child by 1990 or a decade after college, but ten women (14 percent) never had children. Most commonly women had two children (40 percent), but 21 percent had one child, and 24 percent had three children.

We tried to divide the Phase IV respondents into the categories used in Phase II of careerists, breadwinners, homemakers and nesters, based on the combination of their college plans to be employed or not following the birth of their first child and their actual behavior, however we found that real women's lives did not fit as neatly into those four categories more than 25 
years after college graduation. We also found that a significant group of women had part-time employed lives and another group had become entrepreneurs. Thus, we have chosen to focus on four slightly different groups, identifying what their college plans were as we describe their lives. The largest group of women followed a career of full-time work (35 hours or more) and did not leave the labor force for any reason for more than three years regardless of their childrearing responsibilities. Examples of their life stories are described in Chapter 3. This group contains both careerists and breadwinners following the categories we used in Phase II.

The second group did not seem to be apparent during their first decade after college but we now see that they have followed a distinct pattern of part-time work for three or more years during their careers. Their lives are described in Chapter 4 and they might have been called careerists or breadwinners in Phase II.

The third group includes women who have become full-time homemakers for at least three years or more at some time during their life. This includes those who left the labor force after the birth of their first child as well as those who may have kept their positions after the birth of their first child but left to become full-time family caretakers later in life, perhaps after a later childbirth. Thus, this group, whose lives are described in Chapter 5, does not identically match those we called homemakers in Phase II and might also include nesters and some careerists and breadwinners if the women worked after their first childbirth but became homemakers later.

The last group is composed of women who started their own businesses, some as an occupational choice and some because they saw starting a childcare service in their homes as a way to bring in income and stay close to their own children. These women are described in Chapter 6 and include women we might have called homemakers or careerists or breadwinners in Phase II.

Each of the following four chapters contains narratives of individual women's lives. The names have been changed and the narratives were sent to the women we could locate when the manuscript was completed to give them a chance to ask us to disguise any aspects of their lives that might be too identifiable and to check that we had not made errors in describing their lives. Most women had few changes and these usually involved changing locations or dates that might be personally identifiable. In one case, we found that a Phase II questionnaire had been misidentified and this error was corrected. The interview records were coded by the principal investigator and recoded to check for consistency by two research assistants. When coding discrepancies were found, we discussed each case and came to agreement about how each should be coded. A summary of coded responses and the narratives is located at the end of each chapter.

In order to interpret the content of change, factors that influenced the 
change as well as the change process itself, in addition to considering the cultural context changes as well as the sample changes, we can look at two other sources of information: first, previous theory and literature about how women balance work and family across time and second, the stories of the women themselves about what they thought about influences on the critical events in their work and family lives. Chapter 2 will highlight important scholarly theoretical and empirical work in this arena. Chapters 3 through 6 will tell the women's stories of what they did and why they thought they did it, as related in the interviews for Phase IV that were conducted in person or on the telephone during 2006-07. The life stories in each of the chapters in Part II contain information from open and closed ended questions from Phase I, Phase II, and Phase III questionnaires as well as their retrospective accounts of their important life events discussed in Phase IV interviews. The integration of each of these sources of data helps to reduce biases in retrospective memory and to illustrate changes in attitudes and behavior across the years of the study. Final conclusions synthesizing information from all phases and the existing literature are presented in the final chapter.

\section{NOTES}

1. US Census Bureau (2005), 'Table H2. Distribution of women 40 to 44 years old by number of children ever born and marital status: selected years, 1970 to 2004', available at http://www.census.gov/population/socdemo/fertility/tabH2.xls, date accessed 3 October 2006; Bergman, M. (2003), 'Women edge men in high school diplomas, breaking 13-year deadlock', United States Department of Commerce News, CB03-51, available at, http://www.census.gov/Press-Release/www/2003/cb03-ff07.html, date accessed 3 October 2006.

2. O'Connell, M. (2001), 'Labor force participation for mothers with infants declines for first time, census bureau reports', United States Department of Commerce News, CB01-170, available at, http://www.census.gov/Press-Release/www/2001/cb01-170.html, date accessed 3 October 2006.

3. US Department of Labor, Bureau of Labor Statistics (1991), 'Statistical tables', Employment and Earnings, Jan. 199138 (1), Washington, DC: US Government Printing Office; US Census Bureau (2006), 'S2401. Occupation by sex and median earnings in the past 12 months (in 2006 inflation-adjusted dollars) for the civilian employed population 16 years and over', available at, http://factfinder.census.gov/servlet/STTable?_bm=y\&-geo_id= 01000US \&-qr_name=ACS_2006_EST_G00_S2401\&-ds_name=ACS_2006_EST_G00_, date accessed 3 October 2006.

4. Morrison, A.M. and M.A. Von Glinow (1990), 'Women and minorities in management', American Psychologist, 45 (2), 200-208.

5. Arthur, M., S.N. Khapova, and C.P.M. Wilderom (2005), 'Career success in a boundaryless career world', Journal of Organizational Behavior, 26 (2), 177-202; Hall, D.T. and J.E. Moss (1998), 'The new protean career contract: helping organizations and employees adapt', Organizational Dynamics, 26 (3), 22-37; McDonald, P., K. Brown, and L. Bradley (2005), 'Have traditional career paths given way to protean ones? Evidence from senior managers in the Australian public sector', Career Development International, 10 (2), 109-29.

6. Bailyn, L. (2006), Breaking the Mold: Redesigning Work for Productive and Satisfying Lives (2nd edn), Ithaca, NY: ILR Cornell University Press. 
7. USA Presidents-Info, 'Ronald Reagan', available at, http://www.usa-presidents.info/ reagan.htm, date accessed 3 October 2006.

8. The ' 80 s Server, available at, http://www.80s.com/Entertainment/, date accessed 3 October 2006.

9. http://www.authentichistory.com/audio/1980s/1980s_popculture.html, date accessed 3 October 2006.

10. Granrose, C.S. (1985), 'Plans for work careers among college women who expect to have a family', Vocational Guidance Quarterly, 33 (4), 284-95.

11. Granrose, C.S. (1987), 'Intentions to work after childbirth of single and partnered college women', Career Development Quarterly, 36 (1), 66-80.

12. Granrose, C.S. and E. Cunningham (1988), 'Post-partum work intentions among black and white college women', Career Development Quarterly, 37 (2), 149-64.

13. Granrose, C.S. and E.A. Kaplan (1996), Work-Family Role Choices for Women in Their $20 \mathrm{~s}$ and 30s, Westport, CT: Praeger.

14. Granrose, C.S. (1984), 'A Fishbein-Ajzen model of intention to work following childbirth', Journal of Vocational Behavior, 25 (3), 359-72; Granrose, C.S. (1985), 'Anticipating the decision to work following childbirth', Vocational Guidance Quarterly, 33 (3), 221-30; Granrose, C.S. and E.A. Kaplan (1994), 'Returning to work following childbirth: the relationship between intentions and behavior', Journal of Applied Social Psychology, 24 (10), 874-96; Kaplan, E.A. and C.S. Granrose (1993), 'Factors influencing women's decision to leave an organization following childbirth', Employee Responsibilities and Rights Journal, $6(1), 45-54$.

15. USA President-Info, 'George Herbert Walker Bush', available at, http://www.usapresidents. info/bush.htm, date accessed 3 October 2006.

16. http://www.popculturemadness.com/Entertainment/90s-Music.html, date accessed 3 October 2006.

17. http://www.authentichistory.com/1990s.html, date accessed 3 October 2006.

18. Granrose, C.S. and E.A. Kaplan (1996), Work-Family Role Choices for Women in Their $20 \mathrm{~s}$ and 30s, Westport, CT: Praeger.

19. USA Presidents-Info, 'Bill Clinton', available at, http://www.usa-presidents.info/ clinton.htm, date accessed 3 October 2006.

20. USA Presidents-Info, 'George Walker Bush', available at, http://www.usa-presidents.info/ gwbush.htm

21. Gettings, J., '2000 Pop culture trends', available at, http://www.infoplease.com/spot/ 00poptrends1.html, date accessed 3 October 2006.

22. http://en.wikipedia.org/wiki/2000_in_sports\#Baseball, date accessed 3 October 2006.

23. Internet Movie Database, 'Top rated "2000s" titles', available at, http://www.imdb.com/ chart/2000s, date accessed 3 October 2006.

24. http://www.tv.com/shows/topshows.html?pop=1\&tag=subnav;top_shows, date accessed 3 October 2006; About.com, 'Top pop songs of 2005', available at, http://top40.about.com/ od/news/a/pollsingle2005.htm, date accessed 3 October 2006.

25. $\chi_{\mathrm{Sq}}=13.35, \mathrm{df}=4, \mathrm{p}=0.009$.

26. $\chi_{\text {Sq. }}=4.99, \mathrm{df}=1, \mathrm{p}=0.025$.

27. $\mathrm{M}=2.77, \mathrm{SD}=1.29$ for non respondents compared to $\mathrm{M}=3.32, \mathrm{SD}=1.39$, for respondents, $\mathrm{p}=0.04$ on a scale of $1-5$ where $1=$ very unlikely and $5=$ very likely. 